\title{
IMPLEMENTASI KURIKULUM 2013 DAN PEMBELAJARAN PAI
}

\author{
Oleh: Nia Kurniasih 1) \\ NIM. 2.216.3.074 \\ 1) SMA Negeri 1 Ciawi \\ email: ghifarali1979@gmail.com
}

\begin{abstract}
The Government undertakes various arrangements in the standardization system of education, one of which evaluates and develops a new curriculum as it is one of the important components of education. The existence of changes in the structure of the new curriculum certainly has a major impact on learning in schools, one of them on Islamic religious education. This new curriculum is called Curriculum 2013. The focus of this research is how the implementation of the 2013 curriculum on learning PAI in SMAN 1 Ciawi. These include: learning planning and implementation of learning curriculum 2013 on learning subjects PAI and Budi Pekerti. This research is field research with qualitative approach and using qualitative descriptive analysis. The results show that the implementation of curriculum 2013 on learning subjects PAI and Budi Pekerti in SMAN 1 Ciawi, which the teacher has been in accordance with what is desired by the Curriculum 2013 with the application of scientific approach. But the obstacles encountered are the procurement of an incomplete handbook, the use of IT is still very less, and many other obstacles.
\end{abstract}

Keywords:

Implementation, Curriculum 2013, Learning PAI.

\begin{abstract}
Abstrak :Pemerintah melakukan berbagai penataan dalam sistem standarisasi pendidikan, salah satunya mengevaluasi dan menyusun kurikulum baru karena merupakan salah satu komponen pendidikan yang penting. Adanya perubahan struktur kurikulum yang baru tentunya berdampak besar pada pembelajaran di sekolah, salah satunya pada pendidikan agama Islam. Kurikulum baru ini dinamakan Kurikulum 2013. Fokus penelitian ini bagaimana implementasi kurikulum 2013 pada pembelajaran PAI di SMAN 1 Ciawi. Yaiztftu meliputi: perencanaan pembelajaran dan pelaksanaan pembelajaran Kurikulum 2013 pada pembelajaran mata pelajaran PAI dan Budi Pekerti. Penelitian ini adalah penelitian lapangan dengan pendekatan kualitatif serta menggunakan analisis deskriptif kualitatif. Hasil penelitian menunjukkan bahwa implementasi kurikulum 2013 pada pembelajaran mata pelajaran PAI dan Budi Pekerti di SMAN 1 Ciawi, yang dilakukan guru telah sesuai dengan apa yang dikehendaki oleh Kurikulum 2013 dengan penerapan pendekatan saintifik. Tetapi kendala yang dihadapi adalah pengadaan buku pegangan yang belum lengkap, penggunaan TI yang masih sangat kurang, dan banyak lagi kendala yang lainnya.
\end{abstract}

Kata Kunci :

Implementasi, Kurikulum 2013, Pembelajaran PAI.

\section{PENDAHULUAN}

Implementasi kurikulum 2013 yang pada prinsipnya sangat dibutuhkan guru di sekolah adalah penyusunan Rencana Pelaksanaan Pembelajaran. RPP yang disusun guru akan berdasarkan Permendikbud No. 81a Tahun 2013 Lampiran IV Tentang Pedoman Umum Pembelajaran. Kegiatan pembelajaran pada prinsipnya merupakan proses pendidikan yang memberikan kesempatan kepada peserta didik untuk mengembangkan potensi mereka menjadi kemampuan yang semakin lama semakin meningkat dalam sikap, pengetahuan, dan keterampilan yang diperlukan dirinya untuk hidup dan untuk bermasyarakat, berbangsa, serta berkontribusi pada kesejahteraan hidup umat manusia. 
Strategi pembelajaran harus diarahkan untuk memfasilitasi pencapaian kompetensi yang telah dirancang dalam dokumen kurikulum agar setiap individu mampu menjadi pebelajar mandiri sepanjang hayat. dan yang pada gilirannya mereka menjadi komponen penting untuk mewujudkan masyarakat belajar. Untuk mencapai kualitas yang telah dirancang dalam dokumen kurikulum, kegiatan pembelajaran perlu menggunakan prinsip yang: (1) berpusat pada peserta didik, (2) mengembangkan kreativitas peserta didik, (3) menciptakan kondisi menyenangkan dan menantang, (4) bermuatan nilai, etika, estetika, logika, dan kinestetika, dan (5) menyediakan pengalaman belajar yang beragam melalui penerapan berbagai strategi dan metode pembelajaran yang menyenangkan, kontekstual, efektif, efisien, dan bermakna.

Di dalam pembelajaran, peserta didik didorong untuk menemukan sendiri dan mentransformasikan informasi kompleks, mengecek informasi baru dengan yang sudah ada dalam ingatannya, dan melakukan pengembangan menjadi informasi atau kemampuan yang sesuai dengan lingkungan dan jaman tempat dan waktu ia hidup. Kurikulum 2013 menganut pandangan dasar bahwa pengetahuan tidak dapat dipindahkan begitu saja dari guru ke peserta didik. Peserta didik adalah subjek yang memiliki kemampuan untuk secara aktif mencari, mengolah, mengkonstruksi, dan menggunakan pengetahuan. Untuk itu pembelajaran harus berkenaan dengan kesempatan yang diberikan kepada peserta didik untuk mengkonstruksi pengetahuan dalam proses kognitifnya. Agar benarbenar memahami dan dapat menerapkan pengetahuan, peserta didik perlu didorong untuk bekerja memecahkan masalah, menemukan segala sesuatu untuk dirinya, dan berupaya keras mewujudkan ide-idenya.

Guru mengembangkan kesempatan belajar kepada peserta didik untuk meniti anak tangga yang membawa peserta didik kepemahaman yang lebih tinggi, yang semula dilakukan dengan bantuan guru tetapi semakin lama semakin mandiri. Bagi peserta didik, pembelajaran harus bergeser dari "diberi tahu" menjadi "aktif mencari tahu".Di dalam pembelajaran, peserta didik mengkonstruksi pengetahuan bagi dirinya. Bagi peserta didik, pengetahuan yang dimilikinya bersifat dinamis, berkembang dari sederhana menuju kompleks, dari ruang lingkup dirinya dan di sekitarnya menuju ruang lingkup yang lebih luas, dan dari yang bersifat konkrit menuju abstrak.

Di dalam pembelajaran, peserta didik difasilitasi untuk terlibat secara aktif mengembangkan potensi dirinya menjadi kompetensi. Guru menyediakan pengalaman belajar bagi peserta didik untuk melakukan berbagai kegiatan yang memungkinkan mereka mengembangkan potensi yang dimiliki mereka menjadi kompetensi yang ditetapkan dalam dokumen kurikulum atau lebih. Pengalaman belajar tersebut semakin lama semakin meningkat menjadi kebiasaan belajar mandiri dan ajeg sebagai salah satu dasar untuk belajar sepanjang hayat.

Pada Kurikulum 2013 dikembangkan dua modus proses pembelajaran yaitu proses pembelajaran langsung dan proses pembelajaran tidak langsung. Proses pembelajaran langsung adalah proses pendidikan di mana peserta didik mengembangkan pengetahuan, kemampuan berpikir dan keterampilan psikomotorik melalui interaksi langsung dengan sumber belajar yang dirancang dalam silabus dan RPP berupa 
kegiatan-kegiatan pembelajaran. Dalam pembelajaran langsung tersebut peserta didik melakukan kegiatan belajar mengamati, menanya, mengumpulkan informasi, mengasosiasi atau menganalisis, dan mengkomunikasikan apa yang sudah ditemukannya dalam kegiatan analisis. Proses pembelajaran langsung menghasilkan pengetahuan dan keterampilan langsung atau yang disebut dengan instructional effect.

Pembelajaran tidak langsung adalah proses pendidikan yang terjadi selama proses pembelajaran langsung tetapi tidak dirancang dalam kegiatan khusus. Pembelajaran tidak langsung berkenaan dengan pengembangan nilai dan sikap. Berbeda dengan pengetahuan tentang nilai dan sikap yang dilakukan dalam proses pembelajaran langsung oleh mata pelajaran tertentu, pengembangan sikap sebagai proses pengembangan moral dan perilaku dilakukan oleh seluruh mata pelajaran dan dalam setiap kegiatan yang terjadi di kelas, sekolah, dan masyarakat. Oleh karena itu, dalam proses pembelajaran Kurikulum 2013, semua kegiatan yang terjadi selama belajar di sekolah dan di luar dalam kegiatan kokurikuler dan ekstrakurikuler terjadi proses pembelajaran untuk mengembangkan moral dan perilaku yang terkait dengan sikap.Baik pembelajaran langsung maupun pembelajaran tidak langsung terjadi secara terintegrasi dan tidak terpisah. Pembelajaran langsung berkenaan dengan pembelajaran yang menyangkut KD yang dikembangkan dari KI-3 dan KI-4. Keduanya, dikembangkan secara bersamaan dalam suatu proses pembelajaran dan menjadi wahana untuk mengembangkan KD pada KI-1 dan KI-2. Pembelajaran tidak langsung berkenaan dengan pembelajaran yang menyangkut KD yang dikembangkan dari KI-1 dan KI-2.

Implementasi kurikulum 2013 adalah usaha bersama antara Pemerintah dengan pemerintah daerah propinsi dan pemerintah daerah kabupaten/kota.

a. Pemerintah bertanggung jawab dalam mempersiapkan guru dan kepala sekolah untuk melaksanakan kurikulum.

b. Pemerintah bertanggungjawab dalam melakukan evaluasi pelaksanaan kurikulum secara nasional.

c. Pemerintah propinsi bertanggungjawab dalam melakukan supervisi dan evaluasi terhadap pelaksanaan kurikulum di propinsi terkait.

d. Pemerintah kabupaten/kota bertanggungjawab dalam memberikan bantuan profesional kepada guru dan kepala sekolah dalam melaksanakan kurikulum di kabupaten/kota terkait.

Dalam kurikulum 2013, guru dituntut untuk secara profesional merancang pembelajaran afektif dan bermakna, mengorganisasikan pembelajaran, memilih pendekatan pembelajaran yang tepat, menentukan prosedur pembelajaran dan pembentukan kompetensi secara efektif, serta menetapkan kriteria keberhasilan. Berkaitan dengan hal tersebut akan dijelaskan lebih lanjut sebagai berikut:

a. Merancang pembelajaran secar efektif dan bermakna.

Implementasi kurikulum 2013 merupakan aktualisasi kurikulum, dalam pembelajaran dan pembentukan kompetensi serta karakter peserta didik. Hal tersebut menuntut keaktifan guru dalam menciptakan dan menumbuhkan berbagai kegiatan sesuai dengan rencana yang telah diprogramkan. Guru harus menyadari bahwa 
pembelajaran memiliki sifat yang sangat kompleks karena melibatkan aspek pedagigis, psikologi, dan didaktis secara bersamaan.

b. Mengorganisasikan pembelajaran.

Implementasi kurikulum 2013 menuntut guru untuk mrngorganisasikan pembelajaran secara efektif. Sedikitnya terdapat lima hal yang perlu diperhatikan berkaitan dengan pengorgsnisasian pembelajaran dalam implementasi kurikulum 2013, yaitu pelaksanaan pembelajaran, pengadaan dan pembinaan tenaga ahli, pendayagunaan tenaga ahli dan sumber daya masyarakat, serta pengembangan dan penataan kebijakan.

c. Memilih dan menentukan pendekatan pembelajaran.

Implementasi kurikulum 2013 berbasis kompetensi dalam pembelajaran dapat dilakukan dengan berbagai pendekatan. Pendekatan tersebut antara lain pembelajaran kontekstual (contextual teaching and learing), bermain peran, pembelajaran partisipatif(participative teaching and learning), belajar tuntas (mastery learning), dan pembelajaran konstruktivisme(constructivism teaching and learning). Melaksanakan pembelajaran, pembentukan kompetensi, dan karakter. Pembelajaran dalam menyukseskan implementasi kurikulum 2013 merupakan keseluruhan proses belajar, pembentukan kompetensi dan karakter peserta didik yang direncanakan. Untuk kepentingan tersebut maka kompetensi inti, kompetensi dasar, materi standart, indikator hasil belajar, dan waktu yang harus ditetapkan sesuai dengan kepentingan pembelajaran sehinga peserta didik diharapkan memperoleh kesempatan dan pengalaman belajar yang optmal.dalam hal ini, pembelajaran pada hakikatnya adalah proses interaksi antara peserta didik dengan lingkungannya, sehingga terjadi perubahan perilaku kearah yang lebih baik. Pada umumnya kegiatan pembelajaran mencangkup kegiatan awal atau pembukaan, kegiatan inti atau pembentukan kompetensi dan karakter, serta kegiatan akhir atau penutup.

Implementasi yang efektif merupakan hasil dari interaksi antara strategi implementasi, struktur kurikulum, tujuan pendidikan, dan kepemimpinan kepala sekolah. Oleh karena itu, pengoptimalan implementasi kurikulum 2013 diperlukan suatu upaya strategis untuk mensinergikan komponen-komponen tersebut, terutama guru dan kepala sekolah dalam membudayakan kurikulum.

Membudayakan kurikulum dapat diartikan bahwa implementasi kurikulum tersebut masuk dalam budaya sekolah, yang merefleksikan nilai-nilai dominan, normanorma, dan keyakinan semua warga sekolah, baik peserta didik, guru, kepala sekolah, maupun tenaga kependidikan lain. ${ }^{5}$

\section{METODOLOGI PENELITIAN}

Metode penelitian adalah cara yang akan ditempuh oleh peneliti untuk menjawab permasalahan penelitian atau rumusan masalah. Dalam penelitian ini, peneliti menggunakan pendekatan kualitatif yaitu penelitian yang mencoba memahami fenomena dalam seting dan konteks naturalnya (bukan di dalam laboratorium). Dimana peneliti tidak berusaha untuk memanipulasi fenomena yang sedang diamati sehingga 
nantinya penelitian ini berusaha memahami kompleksitas fenomena yang diteliti, yaitu tentang implementasi kurikulum 2013. Penelitian ini menggunakan metode penelitian deskriptif atau metode penelitian deskriptif kualitatif. Penelitian deskriptif adalah penelitian yang bermaksud untuk membuat gambaran mengenai situasi-situasi atau kejadian-kejadian dan mengakumulasikan data dasar dalam cara deskriptif. Penelitian ini memaparkan bagaimana implementasi kurikulum 2013 pada pembelajaran akidah di SMAN 1 Ciawi.

\section{HASIL PENELITIAN DAN PEMBAHASAN}

Suatu hal yang tidak bisa ditawar, bahwa RPP wajib disusun oleh guru sebelum guru masuk kelas. Karena dengan adanya perencanaan guru telah menetapkan segala keperluan serta metode yang harus diterapkan ketika melaksanakan pembelajaran termasuk dapat mengelolah waktu secara efisien. Dengan demikian memungkinkan tujuan pembelajaran mudah dicapai. Oleh karena itu diperlukan model RPP yang memenuhi standar minimal. Berikut deskripsi implementasi pada pembelajaran.

Kegiatan pendahuluan diawali dengan, guru menyiapkan peserta didik secara psikis dan fisik untuk mengikuti proses pembelajaran. Kemudian guru mengajukan pertanyaan-pertanyaan tentang materi yang sudah dipelajari dan terkait dengan materi yang akan dipelajari. Kemudian guru mengantarkan peserta didik kepada suatu permasalahan atau tugas yang akan dilakukan untuk mempelajari suatu materi dan menjelaskan tujuan pembelajaran atau KD yang akan dicapai dan menyampaikan garis besar cakupan materi dan penjelasan tentang kegiatan yang akan dilakukan peserta didik untuk menyelesaikan permasalahan atau tugas.

Selanjutnya, kegiatan inti merupakan proses pembelajaran untuk mencapai tujuan, yang dilakukan secara interaktif, inspiratif, menyenangkan, menantang, memotivasi peserta didik untuk secara aktif menjadi pencari informasi, serta memberikan ruang yang cukup bagi prakarsa, kreativitas, dan kemandirian sesuai dengan bakat, minat dan perkembangan fisik serta psikologis peserta didik. Kegiatan inti menggunakan metode yang disesuaikan dengan karakteristik peserta didik dan matapelajaran, yang meliputi proses observasi, menanya, mengumpulkan informasi, asosiasi, dan komunikasi. Untuk pembelajaran yang berkenaan dengan KD yang bersifat prosedur untuk melakukan sesuatu, guru memfasilitasi agar peserta didik dapat melakukan pengamatan terhadap pemodelan/demonstrasi oleh guru atau ahli, peserta didik menirukan, selanjutnya guru melakukan pengecekan dan pemberian umpan balik, dan latihan lanjutan kepada peserta didik. Dalam setiap kegiatan guru harus memperhatikan kompetensi yang terkait dengan sikap seperti jujur, teliti, kerja sama, toleransi, disiplin, taat aturan, menghargai pendapat orang lain yang tercantum dalam silabus dan RPP. Cara pengumpulan data sedapat mungkin relevan dengan jenis data yang dieksplorasi, misalnya di laboratorium, studio, lapangan, perpustakaan, museum, dan sebagainya. Sebelum menggunakannya peserta didik harus tahu dan terlatih dilanjutkan dengan menerapkannya.

Proses pembelajaran pada Kurikulum 2013 untuk semua jenjang dilaksanakan dengan menggunakan pendekatan ilmiah (saintifik). Langkah-langkah pendekatan 
ilmiah (scientific appoach) dalam proses pembelajaran meliputi menggali informasi melaui pengamatan, bertanya, percobaan, kemudian mengolah data atau informasi, menyajikan data atau informasi, dilanjutkan dengan menganalisis, menalar, kemudian menyimpulkan, dan mencipta. Untuk mata pelajaran, materi, atau situasi tertentu, sangat mungkin pendekatan ilmiah ini tidak selalu tepat diaplikasikan secara prosedural. Pada kondisi seperti ini, tentu saja proses pembelajaran harus tetap menerapkan nilai-nilai atau sifat-sifat ilmiah dan menghindari nilai-nilai atau sifat-sifat nonilmiah. Pendekatan saintifik dalam pembelajaran disajikan sebagai berikut:

\section{a. Mengamati (observasi)}

Kebermaknaan proses pembelajaran (meaningfull learning). Metode ini memiliki keunggulan tertentu, seperti menyajikan media obyek secara nyata, peserta didik senang dan tertantang, dan mudah pelaksanaannya. Metode mengamati sangat bermanfaat bagi pemenuhan rasa ingin tahu peserta didik. Sehingga proses pembelajaran memiliki kebermaknaan yang tinggi. Kegiatan mengamati dalam pembelajaran sebagaimana disampaikan dalam Permendikbud Nomor 81A/2013, hendaklah guru membuka secara luas dan bervariasi kesempatan peserta didik untuk melakukan pengamatan melalui kegiatan: melihat, menyimak, mendengar, dan membaca. Guru memfasilitasi peserta didik untuk melakukan pengamatan, melatih mereka untuk memperhatikan (melihat, membaca, mendengar) hal yang penting dari suatu benda atau objek. Adapun kompetensi yang diharapkan adalah melatih kesungguhan, ketelitian, dan mencari informasi.

\section{b. Menanya}

Dalam kegiatan mengamati, guru membuka kesempatan secara luas kepada peserta didik untuk bertanya mengenai apa yang sudah dilihat, disimak, dibaca atau dilihat. Guru perlu membimbing peserta didik untuk dapat mengajukan pertanyaan: pertanyaan tentang yang hasil pengamatan objek yang konkrit sampai kepada yang abstra berkenaan dengan fakta, konsep, prosedur, atau pun hal lain yang lebih abstrak. Pertanyaan yang bersifat faktual sampai kepada pertanyaan yang bersifat hipotetik. Dari situasi di mana peserta didik dilatih menggunakan pertanyaan dari guru, masih memerlukan bantuan guru untuk mengajukan pertanyaan sampai ke tingkat di mana peserta didik mampu mengajukan pertanyaan secara mandiri. Dari kegiatan kedua dihasilkan sejumlah pertanyaan. Melalui kegiatan bertanya dikembangkan rasa ingin tahu peserta didik. Semakin terlatih dalam bertanya maka rasa ingin tahu semakin dapat dikembangkan. Pertanyaan terebut menjadi dasar untuk mencari informasi yang lebih lanjut dan beragam dari sumber yang ditentukan guru sampai yang ditentukan peserta didik, dari sumber yang tunggal sampai sumber yang beragam.

Kegiatan "menanya" dalam kegiatan pembelajaran sebagaimana disampaikan dalam Permendikbud Nomor 81a Tahun 2013, adalah mengajukan pertanyaan tentang informasi yang tidak dipahami dari apa yang diamati atau pertanyaan untuk mendapatkan informasi tambahan tentang apa yang diamati (dimulai dari pertanyaan faktual sampai ke pertanyaan yang bersifat hipotetik). Adapun kompetensi yang diharapkan dalam kegiatan ini adalah mengembangkan kreativitas, rasa ingin tahu, 
kemampuan merumuskan pertanyaan untuk membentuk pikiran kritis yang perlu untuk hidup cerdas dan belajar sepanjang hayat.

\section{c. Mengumpulkan Informasi}

Kegiatan "mengumpulkan informasi" merupakan tindak lanjut dari bertanya. Kegiatan ini dilakukan dengan menggali dan mengumpulkan informasi dari berbagai sumber melalui berbagai cara. Untuk itu peserta didik dapat membaca buku yang lebih banyak, memperhatikan fenomena atau objek yang lebih teliti, atau bahkan melakukan eksperimen. Dari kegiatan tersebut terkumpul sejumlah informasi. Dalam Permendikbud Nomor 81a Tahun 2013, aktivitas mengumpulkan informasi dilakukan melalui eksperimen, membaca sumber lain selain buku teks, mengamati objek/ kejadian/, aktivitas wawancara dengan nara sumber dan sebagainya. Adapun kompetensi yang diharapkan adalah mengembangkan sikap teliti, jujur,sopan, menghargai pendapat orang lain, kemampuan berkomunikasi, menerapkan kemampuan mengumpulkan informasi melalui berbagai cara yang dipelajari, mengembangkan kebiasaan belajar dan belajar sepanjang hayat.

\section{d. Mengasosiasikan/ Mengolah Informasi/Menalar}

Kegiatan "mengasosiasi/ mengolah informasi/ menalar" dalam kegiatan pembelajaran sebagaimana disampaikan dalam Permendikbud Nomor 81a Tahun 2013, adalah memproses informasi yang sudah dikumpulkan baik terbatas dari hasil kegiatan mengumpulkan/eksperimen maupun hasil dari kegiatan mengamati dan kegiatan mengumpulkan informasi. Pengolahan informasi yang dikumpulkan dari yang bersifat menambah keluasan dan kedalaman sampai kepada pengolahan informasi yang bersifat mencari solusi dari berbagai sumber yang memiliki pendapat yang berbeda sampai kepada yang bertentangan. Kegiatan ini dilakukan untuk menemukan keterkaitan satu informasi dengan informasi lainya, menemukan pola dari keterkaitan informasi tersebut. Adapun kompetensi yang diharapkan adalah mengembangkan sikap jujur, teliti, disiplin, taat aturan, kerja keras, kemampuan menerapkan prosedur dan kemampuan berpikir induktif serta deduktif dalam menyimpulkan.

Aktivitas ini juga diistilahkan sebagai kegiatan menalar, yaitu proses berfikir yang logis dan sistematis atas fakta-kata empiris yang dapat diobservasi untuk memperoleh simpulan berupa pengetahuan. Aktivitas menalar dalam konteks pembelajaran pada Kurikulum 2013 dengan pendekatan ilmiah banyak merujuk pada teori belajar asosiasi atau pembelajaran asosiatif. Istilah asosiasi dalam pembelajaran merujuk pada kemamuan mengelompokkan beragam ide dan mengasosiasikan beragam peristiwa untuk kemudian memasukannya menjadi penggalan memori. Selama mentransfer peristiwa-peristiwa khusus ke otak, pengalaman tersimpan dalam referensi dengan peristiwa lain. Pengalaman-pengalaman yang sudah tersimpan di memori otak berelasi dan berinteraksi dengan pengalaman sebelumnya yang sudah tersedia.

\section{e. Mengkomunikasikan}

Pada pendekatan scientific guru diharapkan memberi kesempatan kepada peserta didik untuk mengkomunikasikan apa yang telah mereka pelajari. Kegiatan ini dapat dilakukan melalui menuliskan atau menceritakan apa yang ditemukan dalam kegiatan 
mencari informasi, mengasosiasikan dan menemukan pola. Hasil tersebut disampikan di kelas dan dinilai oleh guru sebagai hasil belajar peserta didik atau kelompok peserta didik tersebut. Kegiatan "mengkomunikasikan" dalam kegiatan pembelajaran sebagaimana disampaikan dalam Permendikbud Nomor 81a Tahun 2013, adalah menyampaikan hasil pengamatan, kesimpulan berdasarkan hasil analisis secara lisan, tertulis, atau media lainnya.

Guru PAI di SMAN 1 Ciawi sudah menunjukkan langkah-langkah pendekatan saintifik tersebut. Dalam kegiatan mengamati, guru membuka secara luas dan bervariasi kesempatan peserta didik untuk melakukan pengamatan melalui kegiatan: melihat, menyimak, mendengar, dan membaca. Guru memfasilitasi peserta didik untuk melakukan pengamatan, melatih mereka untuk memperhatikan (melihat, membaca, mendengar) hal yang penting dari suatu benda atau objek. Dalam kegiatan mengamati, guru membuka kesempatan secara luas kepada peserta didik untuk bertanya mengenai apa yang sudah dilihat, disimak, dibaca atau dilihat. Guru perlu membimbing peserta didik untuk dapat mengajukan pertanyaan: pertanyaan tentang hasil pengamatan objek yang konkrit sampai kepada yang abstra berkenaan dengan fakta, konsep, prosedur, atau pun hal lain yang lebih abstrak. Pertanyaan yang bersifat faktual sampai kepada pertanyaan yang bersifat hipotetik. Dari situasi di mana peserta didik dilatih menggunakan pertanyaan dari guru, masih memerlukan bantuan guru untuk mengajukan pertanyaan sampai ke tingkat di mana peserta didik mampu mengajukan pertanyaan secara mandiri. Dari kegiatan kedua dihasilkan sejumlah pertanyaan. Melalui kegiatan bertanya dikembangkan rasa ingin tahu peserta didik. Semakin terlatih dalam bertanya maka rasa ingin tahu semakin dapat dikembangkan.

Pertanyaan terebut menjadi dasar untuk mencari informasi yang lebih lanjut dan beragam dari sumber yang ditentukan guru sampai yang ditentukan peserta didik, dari sumber yang tunggal sampai sumber yang beragam. Tindak lanjut dari bertanya adalah menggali dan mengumpulkan informasi dari berbagai sumber melalui berbagai cara. Untuk itu peserta didik dapat membaca buku yang lebih banyak, memperhatikan fenomena atau objek yang lebih teliti, atau bahkan melakukan eksperimen. Dari kegiatan tersebut terkumpul sejumlah informasi. Informasi tersebut menjadi dasar bagi kegiatan berikutnya yaitu memeroses informasi untuk menemukan keterkaitan satu informasi dengan informasi lainnya, menemukan pola dari keterkaitan informasi dan bahkan mengambil berbagai kesimpulan dari pola yang ditemukan.

Kegiatan berikutnya adalah menuliskan atau menceritakan apa yang ditemukan dalam kegiatan mencari informasi, mengasosiasikan dan menemukan pola. Hasil tersebut disampikan di kelas dan dinilai oleh guru sebagai hasil belajar peserta didik atau kelompok peserta didik tersebut. Dalam kegiatan penutup, guru bersama-sama dengan peserta didik dan/atau sendiri membuat rangkuman/simpulan pelajaran, melakukan penilaian dan/atau refleksi terhadap kegiatan yang sudah dilaksanakan secara konsisten dan terprogram, memberikan umpan balik terhadap proses dan hasil pembelajaran, merencanakan kegiatan tindak lanjut dalam bentuk pembelajaran remedi, program pengayaan, layanan konseling dan/atau memberikan tugas baik tugas individual maupun 
kelompok sesuai dengan hasil belajar peserta didik, dan menyampaikan rencana pembelajaran pada pertemuan berikutnya. Untuk mewujudkan suasana kelas yang mendukung proses belajar mengajar, guru PAI SMAN 1 Ciawi melaksanakan :

a. Memanggil setiap murid dengan namanya

b. Selalu bersikap sopan kepada murid,

c. Memastikan bahwa anda tidak menunjukkan sikap pilih kasih terhadap murid tertentu

d. Merencanakan dengan jelas apa yang anda lakukan dalam setiap pelajaran

e. Mengungkapkan kepada murid-murid tentang apa yang ingin anda capai dalam pelajaran ini

f. Dengan cara tertentu melibatkan setiap murid selama pelajaran

g. Memberikan kesempatan bagi murid untuk saling berbicara

h. Bersikaplah konsisten dalam menghadapi murid-murid.

\section{Keefektifan Pembelajaran}

Untuk menciptakan suasana yang dapat menumbuhkan gairah belajar, meningkatkan prestasi belajar siswa, dan lebih memungkinkan guru memberikan bimbingan dan bantuan terhadap siswa dalam belajar, maka diperlukan pengorganisasian kelas yang memadai. Dalam hal ini guru PAI di SMAN 1 Ciawi sudah melakukan beberapa teknik untuk membuat suasana yang efektif dalam pelaksanaan proses pembelajaran.

Suasana belajar yang menyenangkan membuat pembelajaran akan berjalan efektif, apabila suasana pembelajaran tersebut menyenangkan, peserta didik akan lebih Rileks, Bebas dari tekanan, Aman, Menarik, Bangkitnya minat belajar, Adanya keterlibatan penuh, Perhatian peserta didik tercurah, Lingkungan belajar yang menarik (misalnya keadaan kelas terang, pengaturan tempat duduk leluasa untuk peserta didik bergerak), Bersemangat, Perasaan gembira, Konsentrasi tinggi. Suasana pembelajaran yang menyenagkan menghindarkan pembelajaran yang tidak efektif, karena peserta didik tidak Tertekan, Perasaan terancam, Perasaan menakutkan, merasa tidak berdaya, tidak bersemangat, malas/tidak berminat, jenuh/bosan, suasana pembelajaran monoton, pembelajaran tidak menarik siswa.

Pelaksanaan pembelajaran erat kaitannya dengan penciptaan lingkungan yang memungkinkan siswa belajar secara aktif, pengembangan aspek pengetahuan, sikap dan keterampilan siswa, penyesuaian dengan rencana kegiatan dan pengelolaan kelas. Proses belajar mengajar harus berorientasi kepada lingkungan tanpa mengabaikan prinsipprinsip kepribadian, dan hasil pendidikan harus bermanfaat dan dimanfaatkan oleh masyarakat. Kegiatan belajar mengajar dikatakan berhasil dari proses apabila peserta didik terlibat secara aktif baik fisik maupun mental dalam proses belajar mengajar. Adapun beberapa kemampuan yang dimiliki guru PAI di SMAN 1 Ciawi dalam melaksanakan pembelajaran yaitu:

a. Kemampuan Membuka Pelajaran

Membuka pelajaran adalah usaha atau kegiatan yang dilakukan oleh guru dalam kegiatan belajar mengajar untuk menciptakan prakondisi bagi murid agar mental 
maupun perhatian terpusat pada apa yang akan dipelajari sehingga usaha tersebut memberikan efek positif terhadap kegiatan belajar. Kegiatan ini dilakukan oleh guru untuk menciptakan suasana siap mental dan memusatkan perhatian siswa pada hal-hal yang akan dipelajarinya. Pra pembelajaran ini juga dapat dilakukan oleh guru dengan memperhatikan kehadiran, kerapian, ketertiban dan perlengkapan pelajaran siswa.

b. Kemampuan Menguasai Pelajaran

Guru harus mampu menguasai bahan atau materi yang akan diajarkan kepada siswa agar tujuan pembelajaran yang diinginkan dapat tercapai. Rincian materi harus memperjelas dan relevan dengan tema atau pokok bahasan yang akan diajarkan dan harus mempunyai nilai aplikasi yang tinggi.

c. Kemampuan Memberi Penjelasan

Kemampuan menjelaskan dalam pengajaran adalah penyajian informasi secara lisan yang diorganisasi secara sistematika untuk menunjukkan hubungan yang satu dengan yang lain. Tujuan memberikan penjelasan yaitu membimbing murid untuk mendapat dan memahami hukum, dalil, fakta, dan prinsip secara objektif dan bernalar.

d. Kemampuan Menggunakan Metode Pengajaran

Dalam menggunakan metode pengajaran, guru menyesuaikan dengan kondisi dan suasana kelas juga jumlah siswa yang ada di dalam kelas. Metode yang direncanakan harus melibatkan aktivitas siswa dalam proses berupa observasi keterampilan kegiatan keahlian siswa proses belajar mengajar secara terkombinasi. Beberapa metode yang diterapkan dalam proses pembelajaran adalah ceramah, tanya jawab, diskusi, demonstrasi, eksperimen, simulasi, kerja kelompok, karya wisata dan sosio drama.

e. Kemampuan Memanfaatkan Media Pengajaran

Dalam proses belajar mengajar media sangat dibutuhkan karena bila dalam kegiatan pengajaran, ketidakjelasan bahan yang disampaikan dapat dibantu dengan menghadirkan media sebagai perantara. Jadi dapat dipahami bahwa media adalah alat bantu yang dapat disajikan sebagai penyalur pesan dan dapat merangsang pikiran, perasaan dan kemauan siswa sehingga dapat mendorong terjadinya proses belajar pada dirinya.

f. Kemampuan Melibatkan Siswa dalam Proses Pembelajaran

Mengajar adalah upaya dalam memberi perangsang (stimulus), bimbingan, pengarahan dan dorongan kepada siswa agar terjadi proses belajar. Peran aktif dari siswa sangat bagus dalam kegiatan belajar mengajar sehingga tercapai tujuan instruksional. Guru mampu untuk menyiapkan kondisi psikologis siswa dalam pembelajaran agar dapat tenang dalam menerima pelajaran yang diberikan.

g. Kemampuan Menggunakan Waktu yang Efisien

Salah satu hambatan yang sering dialami dalam mengajar adalah soal waktu. Seringkali seseorang mengajar tidak dapat mengendalikan waktu. Akibatnya bisa terjadi bahan pelajaran sudah selesai, namun waktu masih panjang. Atau sebaliknya, waktu sudah habis, bahan belum tuntas. Hal ini membawa pengaruh terhadap proses belajar mengajar yang dilaksanakan. Guru PAI di SMAN 1 Ciawi telah mampu membuat pengaturan waktu yang akurat dan efektif. Pengaturan waktu dikatakan baik apabila ada 
kesesuaian antara waktu yang digunakan sebagai materi pelajaran. Materi yang cukup sulit tentu membutuhkan waktu yang lebih lama daripada materi yang cukup mudah, begitu pun dengan materi pelajaran yang membutuhkan praktek di laboratorium dan yang tidak membutuhkan praktek.

h. Kemampuan Menutup Pelajaran

Menutup pelajaran adalah kegiatan yang dilakukan oleh guru untuk mengakhiri pelajaran atau kegiatan belajar mengajar. Usaha menutup pelajaran itu dimaksudkan untuk memberi gambaran menyeluruh tentang apa yang telah dipelajari oleh siswa, mengetahui tingkat pencapaian siswa dan tingkat keberhasilan guru dalam proses belajar mengajar. Usaha guru PAI di SMAN 1 Ciawi dalam mengakhiri kegiatan pelajaran dapat dilakukan guru dengan meninjau kembali penguasaan inti pelajaran dengan merangkum inti pelajaran dan membuat ringkasan. Selain itu, mengakhiri pelajaran ini dengan saransaran misalnya meminta siswa untuk mempelajari kembali di rumah tentang bahan yang baru saja dipelajari.

Ada beberapa 8 masalah yang dihadapi dalam penerapan kurikulum 2013 suka tidak suka mau tidak mau perubahan kurikulum sudah dilaksanakan dengan beberapa mekanisme yang telah dilakukan, tetapi bisa dibilang banyak sekali penolakan yang terjadi ketika membahas kurikulum 2013 banyak sekali kendala dan masalah yang dihadapi hal ini semata-mata karena beberapa faktor yang menjadi masalah besar dalam penerapan kurikulum 2013.

Ada setidaknya 8 masalah yang dihadapi dalam penerapan kurikulum 2013 ini hal ini dikarena beberapa faktor sebagai berikut : 1. Sulitnya mengubah mindset guru, 2) Perubahan proses pembelajaran dari teacher centered ke student centered, 3) rendahnya moral spiritual, budaya membaca dan meneliti masih rendah. 4) Kurangnya penguasaan IT Oleh Guru. 5) lemahnya penguasaan bidang administrasi, 6) kecenderungan guru yang lebih banyak menekankan aspek kognitif. Padahal, semestinya guru juga harus memberikan porsi yang sama pada aspek afektif dan psikomotorik. 7) masih banyak guru yang belum mau menjadi manusia pembelajar. Padahal. 8) seorang guru dituntut untuk terus menambah pengetahuan dan memperluas wawasannya, terlebih setelah diberlakukannya kurikulum 2013.

Pada intinya kurikulum 2013 ini menuntut guru lebih kreatif dan inovatif dalam proses pengajaran, seperti biasa hal yang baru akan mendapat penolakan karena sudah nyaman dengan proses pembelajaran yang sudah dilakukan sebelumnya, selain itu masih banyak sekali sekolah yang belim menggunakan kurikulum 2013 dengan alasan masih belum mampu, terutama sekolah yang berada di daerah.

\section{SIMPULAN}

Dalam pembelajanan PAI terdapat langkah-langkah pelaksanaan Kurikulum 2013 di SMAN 1 Ciawi yaitu : a. perencanaan dilakukan guru dengan menyiapkan perangkat pembelajaran yang mengacu pada Depag yang tentu saja isinya tetap mengacu pada rambu-rambu dan tujuan kurikulum yang berlaku b. pelaksanaan dengan jalan 1) Pembelajaran di lakukan di dalam kelas. 2) Metode ceramah masih mendominasi 
jalannya pembelajaran meskipun tidak semua guru, sehingga pembelajaran masih berpusat pada guru. 3) Tanya jawab yang di terapkan sudah nampak atau sudah mendapat respon dari siswa. 4) Diskusi sudah berjalan dengan baik karena terdapat banyak siswa yang aktif dan berani menyampaikan pendapat. 5) Sarana sehari-hari yang digunakan masih menggunakan pada LKS yang dimiliki siswa, buku paket, papan tulis di kelas dan alat tulis, akan tetapi pada materi tertentu LCD proyektor dan media-media yang diperlukan juga digunakan untuk kelancaran proses pembelajaran 6) Membaca alqur'an telah dilakukan bersamasama di awal dan hafalan surat-surat pendek berjalan dengan baik 7) Sebelum pembelajaran di akhiri, siswa di beri tugas atau evaluasi.

\section{DAFTAR PUSTAKA}

Desmita. (2011). Psikologi Perkembangan Peserta Didik. Bandung : PT. Remaja Rosdakarya.

Amri. 2013. Pengembangan \& Model Pembelajaran dalam Kurikulum 2013. Jakarta :

PT Prestasi Pusta Karya.

Kunandar. 2013. Penilaian Autentik (Penilaian Hasil Belajar Peserta Didik

Berdasarkan Kurikulum 2013). Jakarta : Rajawali Pers

Mulyasa. 2013. Pengembangan dan Implementasi Kurikulum 2013. Bandung Rosda

Karya

Undang-Undang No. 20, Tahun 2003. Pasal 3.

http://intanelmumtaz.blogspot.co.id/2013/12/makalah-implementasi-kurikulum-

2013.html 